\title{
PITTA, Eduardo. Um rapaz a arder. Lisboa: Quetzal, 2013. 240 p.
}

Edgard Pereira Universidade Federal de Minas Gerais

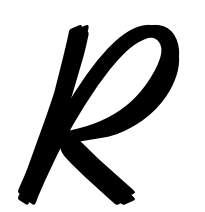

etirado de um poema de Archote glaciar, (quinta coletânea poética do autor, de 1988), Um rapaz a arder nomeia um livro de memórias do escritor moçambicano Eduardo Pitta, que cobre em dez capítulos o período incluso entre 1975 e 2001 . Vale dizer: desde a saída de Lourenço Marques, aturdida e em chamas com as lutas da independência, para fixar-se em Lisboa, chacoalhada ainda pelos ares trepidantes da Revolução dos Cravos. Inicia-se com o relato das marchas e contratempos da luta anticolonial em África, termina com a destruição das torres gêmeas em Nova Iorque, o terror nos dois extremos. Imerso na rota dos confrontos, surge como escritor em Moçambique, um ano antes de abandonar o país: "Foi na ressaca dessa turbulência que saiu o meu primeiro livro, Sílaba a sílaba". O primeiro capítulo, "Próspero \& Caliban", apresenta em síntese o movimento que redundou na independência do país africano. "Ao contrário de Angola, onde três partidos disputavam pelas armas o poder, a independência de Moçambique deu-se sem sobressalto de maior". A ser verdadeira esta assertiva, é também exato que após a independência, o caldo transborda e os confrontos violentos, a barbárie e a matança indiscriminada de opositores recrudescem. Não confundir "sem sobressalto de maior" com manifestação pacífica e ordeira, alguns milhares já estavam 
mortos em junho de 1975, muitos em execuções sumárias. Em 1990, dois anos antes do acordo de paz entre duas facções (a Frelimo e a Renamo), um milhão de pessoas foram dadas como mortas nos conflitos.

O alcance cosmopolita e a veemência na expressão da identidade gay, evidentes na primeira nota de pé de página, evidenciam um registro histórico que não se contenta com a pintura confortável do quintal doméstico. Ao contrário, quem se debruça no tempo carrega o estigma de ter duas pátrias, ressentido pela proscrição de uma delas; traz ecos das mutilações e extermínios, perpetrados em nome de dominação e poder. Quando remexe no passado, funde a historia pessoal à do país em cujo sol nasceu e se formou, estabelece vínculos profundos entre a luta libertária de um povo à experiência, que também se pretende da mesma natureza, do corpo. Como falar de nação, pátria, quando as circunstâncias inóspitas afugentam e amedrontam? As questões de gênero, um dos eixos fundamentais, são tratadas mais sob a clave de Gore Vidal do que de Gide, priorizam aspectos da evolução e formas consuetudinárias da postura gay em detrimento de sua justificação e urgência. A irreverência, a ironia e a elegância pontuam o estilo ágil, direto, incisivo, por vezes insolente e esnobe.

A princípio exilado em Portugal, Eduardo Pitta envolvese por inteiro na vida cultural de Lisboa, vista como cidade adotada para sempre: passa a colaborar na revista Colóquioletras, mantém uma produtiva atuação na Ler, assina crítica literária em jornais, aos poucos vai moldando seu espaço no cenário da cultura portuguesa. "Oriundo de Moçambique, homossexual assumido, com amigos à esquerda e à direita três óbices sérios nos anos 70 portugueses -, eu era uma avis rara". Enquanto publica seus livros (de poesia, ficção e crítica), faz e consolida amizades, em especial na área jornalística e literária. Sobretudo, convive com grandes nomes da literatura 
e das artes plásticas dos últimos vinte e cinco anos. O testemunho acerca dos bastidores da cena literária revela um sagaz observador das relações sociais e do perfil humano de alguns escritores que se tornaram nomes incontornáveis da produção contemporânea. Algumas indiscrições vêm a calhar, a maioria talvez conhecida, outras nem tanto, exemplares do registro frívolo de crônica social panorâmica que perpassa o grosso das memórias. O fenômeno de Portugal a se reencontrar com suas fronteiras européias, jogado no processo de descolonização, é visto pela ótica de um estrangeiro que acompanha, de forma panorâmica, o movimento de redemocratização do país. Poupa-nos, por seu turno, de repisar questões sociológicas a respeito das mutações históricas, observadas nas últimas quatro décadas.

Para além do enfoque político, outras pautas são abordadas, das artes plásticas às viagens internacionais (Grécia, Nova Iorque, Rio de Janeiro e Paris), das boates gays aos restaurantes da moda. A estadia de três meses no Brasil nos anos oitenta, com a inflação na estratosfera, a ditadura militar agonizante e a seleção de futebol encantando o mundo com um futebol vistoso mas de resultados pífios, rende oito páginas de registro direto, com direito a óperas no Municipal, visita ao escritor Lêdo Ivo e tiradas irônicas que buscam condensar o feitio descompromissado do carioca: “...o Rio é glossy e cafageste em doses iguais". Alguns intelectuais merecem maior atenção, seja pela origem moçambicana (Rui Knopfli, Eugênio Lisboa, Alberto de Lacerda, Guilherme de Melo), partilha de interesses ou o sortilégio gratuito da amizade, noutros casos. Nos capítulos finais, são feitas revelações em torno do que seria o perfil arredio, conservador e vaidoso de $\mathrm{Al}$ Berto. Os supostos vínculos entre vida e arte nem sempre abonam conclusões definitivas. Num percurso de documentário, em que a miopia e a lupa se alternam, os 
incidentes ligados à morte de poetas sucedem-se, de entremeio a informações banais sobre gatos domésticos e o sucesso de Saramago: "Nenhum escritor português, vivo ou morto, foi alvo de uma projeção com tal magnitude. Nem mesmo Pessoa". Ao revelar a convivência com os amigos, as palavras saem úmidas de afeto e de cumplicidade. As páginas sobre efemérides, produção de obras, eventos e prêmios, o cotidiano em torno do que se chama vida literária, temperamento e idiossincrasias de um e outro escritor, descontado o gosto pela autoexibição, dão azo a que seja delineado um mosaico rico e variado de um período de ouro da literatura portuguesa, compreendido entre 1970 a 2000.

O esforço de expandir o relato e os comentários pode ser observado no cuidado com que as notas bibliográficas suplementam o texto principal, adicionando detalhes e complementando os dados. Fartamente enriquecido com fotos, o livro traz índice onomástico e destaca-se ainda pelo apuro e qualidade do acabamento gráfico. 